EESTI NSV TEADUSTE AKADEEMIA TOIMETISED. 29. KOIDE KEEMIA. 1980, NR. 3

ИЗВЕСТИЯ АКАДЕМИИ НАУК ЭСТОНСКОИ ССР. ТОМ 29 ХИМИЯ. 1980 , № 3

удК $661.185 .223 .5: 66.098$

А. КУУСК, Реет ПРИИМАН, С. ФАЙНГОЛЬД

\title{
БИОХИМИЧЕСКОЕ РАЗЛОЖЕНИЕ ДИАЛКИЛФЕНИЛСУЛЬФОНАТОВ
}

A. KUUSK, Reet PRIIMAN, S. FAINGOLD. DIALKUOLFENOULSULFONAATIDE BIOKEEMILINE LAGUNEMINE

A. KUUSK, Reet PRIIMAN, S. FAINGOLD. BIODEGRADATION OF DIALKYLPHENYLSULPHONATES

\section{(Представил О. Эйзен)}

Диалкилфенилсульфонаты (ДАФС) относятся к алкиларилсульфонатам, которые являются важнейшими анионными поверхностно-активными веществами. Моющие средства на основе алкилфенилсульфонатов оцениваются в настоящее время как умеренно биологически разлагаемые [']. Нами было синтезировано шесть индивидуальных веществ и один технический продукт типа ДАФС $\left[{ }^{2}\right]$ и исследована степень их биохимического разложения (таблица).

Биохимическая разлагаемость оценивалась путем измерения количества потребленного кислорода в процессе разложения с помощью прибора Варбурга при $25^{\circ} \mathrm{C}$ и продолжительности опытов $6 \boldsymbol{q}^{[3]}$. Концентрация исследуемых ДАФС в растворе составляла 10 мг/л. Эталоном для сравнения служил втор. додецилфенилсульфонат натрия фирмы «Austrowaren» с т. пл. $192-195^{\circ}$ (с разложением).

Биохимическая разлагаемость у втор. ДАФС и технического ДАФС-1 находится в пределах $62-71,5 \%$, причем втор. додецилфенилсульфонат натрия разлагается в условиях опыта до $72,9 \%$. Биоразлагаемость втор. диалкил-ФС-Na уменьшается с увеличением моле-

Изменение степени биоразлагаемости во времени при $25^{\circ} \mathrm{C}$. 1 Додецил-ФС-Na, 2 - ДАФС-1, 3 - втор. диоктил-ФС-Na, 4 пара-ди-н-октил-ФC-Na.

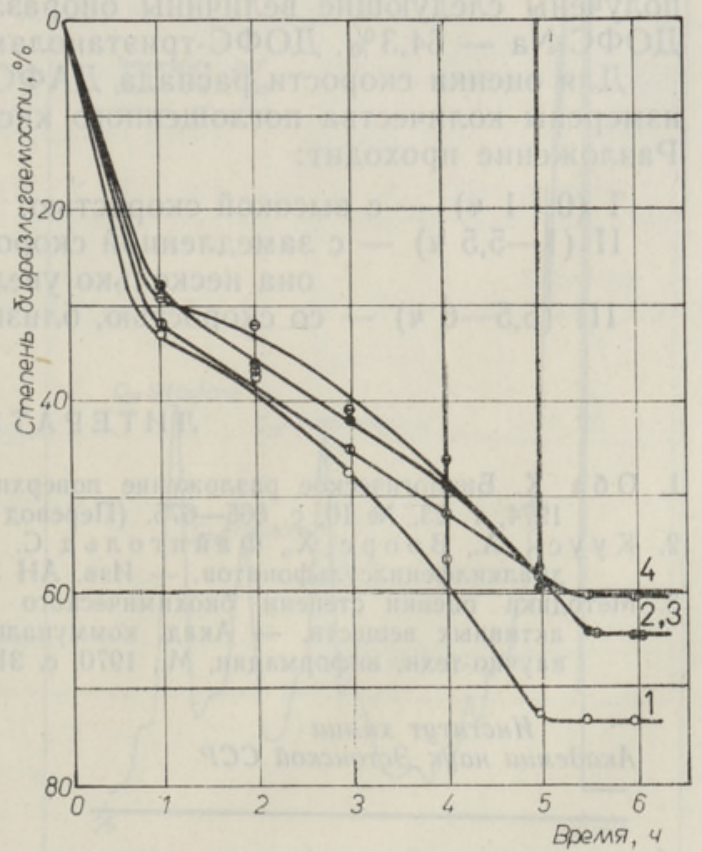


Биоразложение диалкилфенилсульфонатов в аэротенках

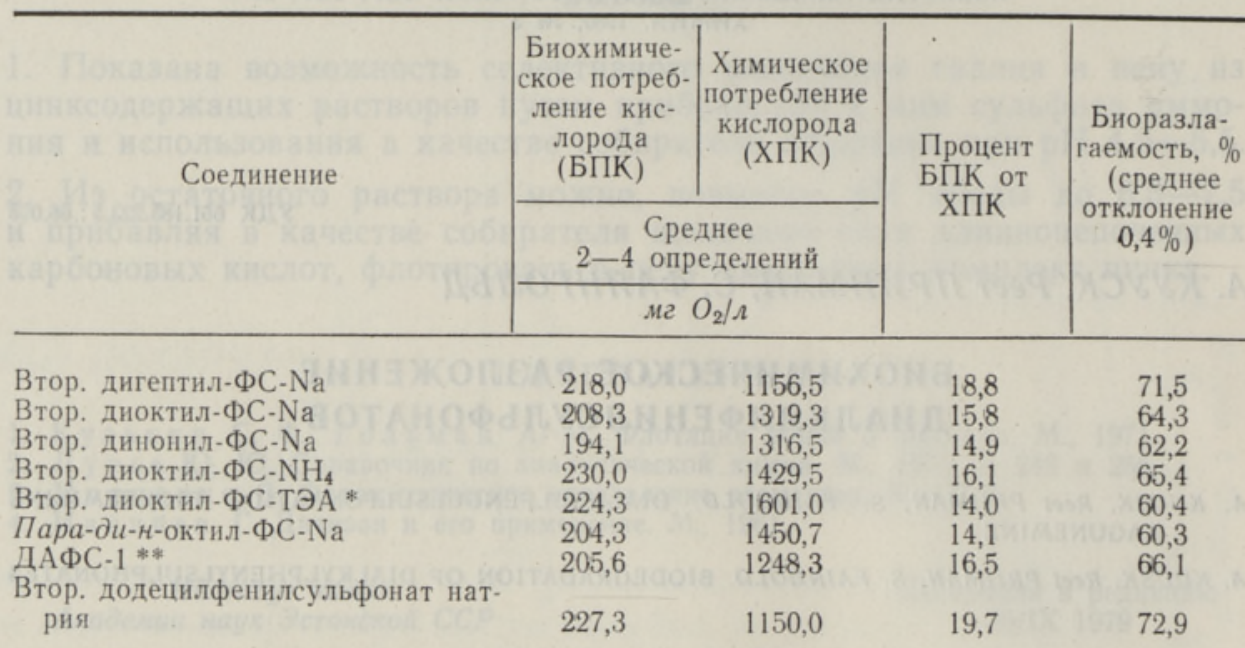

* ТЭА - триэтаноламин.

** Технический продукт, который синтезирован на основе диалкилбензолов, полученных двухступенчатым алкилированием бензола $\alpha$-олефинами, выкипающими в интервале $140-180^{\circ}\left[{ }^{2}\right]$.

кулярного веса соединения в ряду: дигептил $(71,5 \%)>$ диоктил $(64,3 \%)>$ динонил $(62,2 \%)$.

ДАФС с прямолинейной алкильной цепью разлагается труднее, чем соединения с разветвлением алкильной цепи непосредственно у бензольного ядра. Так, пара-дu-н-октил-ФС-Na разлагается до 60,3\%, а втор. диоктил-ФС-Na - до $64,3 \%$.

У втор. диоктил-ФС (ДОФС) в зависимости от типа катиона были получены следующие величины биоразложения: ДОФС-- $\mathrm{NH}_{4}-65,4 \%$, ДОФС-Na - 64,3\%, ДОФС-триэтаноламина $-60,4 \%$.

Для оценки скорости распада ДАФС в ходе опытов (рисунок) были измерены количества поглощенного кислорода (на приборе Варбурга). Разложение проходит:

I $(0-1 u)-$ с высокой скоростью;

II $(1-5,5 u)$ - с замедленной скоростью, причем в конце стадии она несколько увеличивается;

III $(5,5-6 u)$ - со скоростью, близкой к нулю.

\section{Л И Т Р А Т У $\mathrm{PA}$}

1. О ба К. Биологическое разложение поверхностно-активных веществ. - Юкагаку, 1974 , т. 23, № 10, с. $665-675$. (Перевод ВЦП НТЛ и Д 50266, М., 1975.)

2. Кууск А., Вооре Х., Фа й нгольд С. Синтез индивидуальных и технических диалкилфенилсульфонатов. - Изв. АН ЭССР. Хим., 1979, т. 28, № 4, с. 2.

3. Методика оценки степени биохимического распада синтетических поверхностноактивных веществ. - Акад. коммунальн. хоз. им. К. Д. Памфилова. Отдел научно-техн, информации, М., 1970 , с. 31. 